\title{
Metastable Ion Study of Substituted Cyclopentadienylmanganese Cations in the Gas Phase
}

\author{
Dmitri V. Zagorevskii \\ Chemistry Department, University of Ottawa, Ottawa, Ontario, Canada, and Institute of Organo-Element \\ Compounds, Russian Academy of Sciences, Moscow, Russia, CIS
}

\section{Yurii S. Nekrasov}

Institute of Organo-Element Compounds, Russian Academy of Sciences, Moscow, Russia, CIS

John L. Holmes

Chemistry Department, University of Ottawa, Ottawa, Ontario, Canada

\begin{abstract}
The behavior of some substituted cyclopentadienylmanganese ions has been studied by tandem mass spectrometry. This metastable ion study showed that only $\mathrm{C}_{5} \mathrm{H}_{5} \mathrm{Mn}^{+}$and $\left(\mathrm{C}_{5} \mathrm{H}_{4} \mathrm{CN}\right) \mathrm{Mn}^{+}$ions retain their nido-cluster structure (1), which is characterized by a simple metal-ligand bond cleavage. Other substituted ions, $\mathrm{RXC}_{5} \mathrm{H}_{4} \mathrm{Mn}^{+}$, rearrange to a different extent, depending on the nature of the substituent. The first rearrangement step is $R$ radical migration to the central metal atom, leading to $\mathrm{RMnC}_{5} \mathrm{H}_{4} \mathrm{X}^{+}$-type ions (2). These ions decompose by elimination of $X$ (for $X=\mathrm{CO}$ ) or with formation of $\mathrm{RMn}^{+}$, but further rearrangements can also occur. These are the reverse migration of $R$ from the metal atom to the $\pi$-ligand (for $\mathrm{R}=\mathrm{H}, \mathrm{Ph}$ ) and cyclopentadienyl ring expansion (for $\mathrm{X}=\mathrm{CH}$ ). Collisionlal activation mass spectra contained an $\mathrm{Mn}^{+}$ion peak, which can indicate the existence of stable type 1 structures for most cyclopentadienylmanganese ions. Carboxyl and hydroxymethyl derivatives exist, presumably as ions of type 2 . The neutralization-reionization mass spectra of $\mathrm{RXC}_{5} \mathrm{H}_{4} \mathrm{Mn}^{+}$ions are also discussed. (I Am Soc Mass Spectrom 1993, 4, 216-222)
\end{abstract}

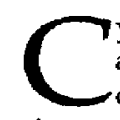

yclopentadienyl nido clusters of transition metals play an important role in organometallic chemistry. They are used, for example, as in situ reagents for the synthesis of polynuclear complexes [1]. In the condensed phase these ions presumably exist as solvated species [1]. Nido clusters with functional groups on the substituent have been studied less than their unsubstituted or polyalkylated analogues.

The characteristic fvature of the gas-phase nido clusters of type $\mathrm{RXC}_{5} \mathrm{H}_{4} \mathrm{Mn}^{+}(1 ; \mathrm{R}=$ halogen, hydroxyl, alkyl, etc.; $\left.X=\mathrm{CO}, \mathrm{CH}_{2}\right)$ is their rearrangement into ions of type 2 (Sclueme $I$ ). The relative capabilities of nido-cluster ions for this isomerization was estimated by the analysis of decomposition pathways of these ions in the ion source of a mass spectrometer [2] or by the study of their ion-molecule reactions with crown ethers [3]. In the ion source

Address reprint requests to John L. Holmes, Department of Chemistry, University of Ottawa, 140 Louis Pasteur $r$ Ottawa, Ontario, Canada K1N 6N5.

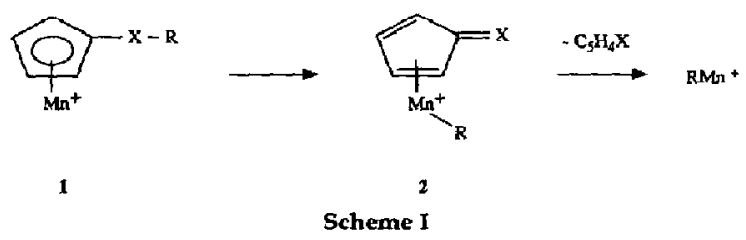

reactions, cyclopenladienyl metal iuns usually arise from several pathways [2] and can be generated via processes involving a wide range of internal energies; this complicates the correct interpretation of experimental data. In this work, the behavior of metastable mass-selected ions was studied using tandem mass spectrometry, where a much narrower range of ion energies is involved and where it may be ascertained whether rearrangement precedes fragmentation.

For the generation of unsolvated nido-cluster $\mathrm{RXC}_{5} \mathrm{H}_{4} \mathrm{Mn}^{+}$ions (1a-1h), the corresponding tricarbonylmanganese compounds were evaporated and ionized by electron impact. In all cases, and in agree- 
ment with other work $[2,4]$, intense signals for the appropriate peaks were observed.

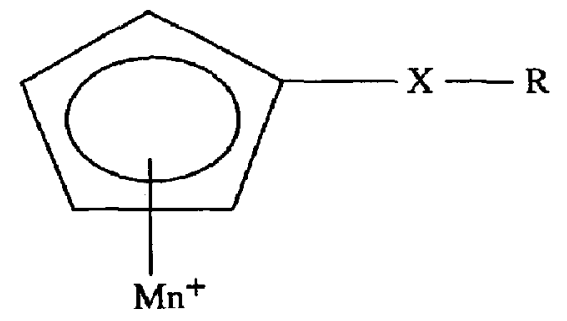

1a - 1 h

\section{Experimental}

Cyclopentadienyltricarbonylmanganese and methylcyclopentadienyltricarbonylmanganese were purchased from Aldrich Chemical Co. (Milwaukee, WI). The other compounds were synthesized as described elsewhere [5].

Electron-impact, metastable ion (MI), collisionalactivation (CA), and neutralization-reionization (NR) mass spectra were recorded using a modified VG Analytical $\mathrm{ZAB}-2 \mathrm{~F}$ mass spectrometer [6]. In CA experiments, He or $\mathrm{Xe}$ was used as collision gases. In NR experiments, $\mathrm{Xe}$ and $\mathrm{O}_{2}$ were used for neutralization and reionization, respectively. In both cases, the pressure of the gas in the first collision cell of the second field-free region was adjusted to give a main beam transmission of $90 \%$, which corresponds to essentially single-collision conditions. The pressure of $\mathrm{O}_{2}$ in the second collision cell reduced the main beam by approximately $15 \%$.

\section{Results and Discussion}

The MI mass spectra of ions $1 \mathbf{a}-1 \mathbf{h}$ are listed in Table 1, from which it can be seen that the decomposition pathways of metastable $\mathrm{RXC}_{5} \mathrm{H}_{4} \mathrm{Mn}^{+}$ions are very sensitive to the nature of the $\mathrm{RX}$ group.

$$
\mathrm{C}_{5} \mathrm{H}_{5} \mathrm{Mn}^{+} \text {and } \mathrm{MnC}_{5} \mathrm{H}_{4} \mathrm{CN}^{+} \text {Ions }
$$

The unsubstituted cyclopentadienylmanganese ion and its cyano derivative show only one peak in their MI

$\begin{array}{ll}\text { a } & X, \mathrm{R}=-, \mathrm{H} \\ \text { b } & \mathrm{X}, \mathrm{R}=-, \mathrm{CN} \\ \text { c } & X, \mathrm{R}=\mathrm{CO}, \mathrm{CH}_{3} \\ \text { d } & \mathrm{X}, \mathrm{R}=\mathrm{CO}, \mathrm{C}_{6} \mathrm{H}_{5} \\ \text { e } & X, \mathrm{R}=\mathrm{CO}, \mathrm{OH} \\ \text { f } & \text { X, R }=\mathrm{CO}, \mathrm{H} \\ \text { g } & \text { X, R }=\mathrm{CH}_{2}, \mathrm{H} \\ \text { h } & \text { X, R }=\mathrm{CH}_{2}, \mathrm{OH}\end{array}$

mass spectra, namely, the $\mathrm{Mn}^{+}$ion. This is generated from a simple metal-ligand bond cleavage, and its formation has been proposed as indicating the presence of the nido-cluster structure $[2,3,4 \mathrm{~d}, 4 \mathrm{f}]$. The $\mathrm{C}_{5} \mathrm{H}_{5}^{+}$ion is absent in the $\mathrm{MI}$ mass spectrum of $\mathrm{C}_{5} \mathrm{H}_{5} \mathrm{Mn}^{+}$. This can readily be explained by the higher endothermicity of the reaction, leading to $\mathrm{Mn}(280 \mathrm{~kJ}$ $\left.\mathrm{mol}^{-1}\right)+\mathrm{C}_{5} \mathrm{H}_{5}^{+}\left(1052 \mathrm{~kJ} \mathrm{~mol}^{-1}\right)$ relative to that for the formation of $\mathrm{Mn}^{+}\left(997 \mathrm{~kJ} \mathrm{~mol}{ }^{-1}\right)+\mathrm{C}_{5} \mathrm{H}_{5}(241 \mathrm{~kJ}$ $\left.\mathrm{mol}^{-1}\right)^{1}$ The same reason applies to the cyanocyclopentadienylmanganese ion.

In both cases, the experimental results can be also explained in terms of the Stevenson-Audier rule [8]: The manganese atom ionization energy $(7.435 \mathrm{eV})$ is indeed lower than ionization energies for $\mathrm{C}_{5} \mathrm{H}_{5}$ (8.69 $\mathrm{eV}$ [9]) and $\mathrm{NCC}_{5} \mathrm{H}_{4}^{-}$(9.44 $\mathrm{eV}$ (9]). The large difference between the ionization energies of the metal atom and the organic ligand leads to the exclusive elimination of the latter as the neutral particle from low-energy (metastable) ions.

${ }^{1}$ All thermochemical data are taken from ref 7 , unless separately referenced

Table 1. Metastable ion mass spectra of $\mathrm{LMn}^{+}\left(\mathrm{L}=\mathrm{RXC}_{5} \mathrm{H}_{4}\right)$ ions 1a-1h

\begin{tabular}{|c|c|c|c|c|c|c|c|}
\hline & $\mathrm{Mn}^{+}$ & $\mathbf{L}^{+}$ & $\mathrm{MnR}^{+}$ & $\mathrm{Mn}(\mathrm{L}-\mathrm{R})^{+}$ & $\mathrm{Mn}(\mathrm{L}-\mathrm{CO})^{+}$ & $\mathrm{Mn}\left(\mathrm{L}-\mathrm{H}_{2} \mathrm{O}\right)^{+}$ & $Z^{a}$ \\
\hline $1 \mathbf{a}$ & 100 & - & - & - & - & - & $<0.01$ \\
\hline $1 \mathrm{~b}$ & 100 & - & - & - & - & - & $<0.01$ \\
\hline 10 & - & 5 & 100 & 5 & - & 4 & 13 \\
\hline $1 d^{b}$ & - & 3 & 20 & - & 100 & - & 25 \\
\hline $1 e^{b}$ & - & - & 100 & - & 2 & 9 & $\approx 100$ \\
\hline 14 & - & 100 & - & - & - & - & $>100$ \\
\hline $1 \mathrm{~g}$ & - & 100 & 6 & 1 & - & - & $>100$ \\
\hline $1 h^{b}$ & - & - & 100 & - & - & 26 & 5.5 \\
\hline
\end{tabular}

See text for explanation of $Z$ values.

Other ions: (1 d) $\mathrm{C}_{5} \mathrm{H}_{4} \mathrm{Ph}^{+},<1$; (1e) $\mathrm{C}_{5} \mathrm{H}_{5} \mathrm{Mn}^{+}, 2$; $\mathrm{Mn}(L-H)^{+}, 3$; and $(1 \mathrm{~h}) \mathrm{Mn}(\mathrm{L}-\mathrm{H})^{+}, 7$; $\mathrm{Mn}(\mathrm{L}-$ $\left.\mathbf{H}_{2}\right)^{+}, 36$. 


\section{Carbonyl Derivatives $\mathrm{MnC}_{5} \mathrm{H}_{4} \mathrm{COR}^{+}$}

The MI mass spectra of ions $1 \mathrm{c}-1 \mathrm{e}$ are also characterized by the presence of abundant manganesecontaining fragments. Organic ions, $\mathrm{RCOC}_{5} \mathrm{H}_{4}^{++}$are observed in the MI mass spectra of acetyl and benzoyl derivatives (Table 1), but they originate not from the simple metal-ligand bond cleavage in type 1 ions; the mechanism of their formation is discussed later.

The rido-cluster structure of type 1 ions is responsible for the formation of some ions in the MI mass spectrum of the acetyl derivative (1c). This is exemplified by $\mathrm{H}_{2} \mathrm{O}$ elimination, which according to previous work [10], results from keto-enol isomerization in the acyl group.

The $\mathrm{CH}_{3}$ radical loss can also proceed from the intact 1c structure by direct $\mathrm{C}-\mathrm{C}$ bond cleavage in the substituent, but possibly it occurs via migration of $\mathrm{CH}_{3}$ to $\mathrm{Mn}$, followed by $\mathrm{Mn}-\mathrm{CH}_{3}$ bond dissociation in the ion (2c).

The rearrangement of substituted cyclopentadienyl metal ions into type 2 structures has been emphasized in much previous work $[2,3,4 \mathrm{~d}, 4 \mathrm{f}, 11]$. The formation of $\mathrm{MnR}^{+}$ions was considered to be the main characteristic of decomposing ions of type 2 (Scheme I). These $\mathrm{MnR}^{+}$ions are the most abundant species in the MI mass spectrum of $\mathbf{~} \mathbf{c}$ and have a moderate intensity in the MI mass spectrum of the benzoyl derivative $1 \mathrm{~d}$. The most abundant $\mathrm{MI}$ peak for $1 \mathrm{~d}$ corresponds to $\mathrm{MnC}_{5} \mathrm{H}_{4} \mathrm{C}_{6} \mathrm{H}_{5}^{+}$, whose formation can also result from precursor $2 \mathrm{~d}$ by the elimination of $\mathrm{CO}$. Loss of $\mathrm{CO}$ is proposed to be followed by the migration of the phenyl group onto the $\mathrm{C}_{5} \mathrm{H}_{4}$ ligand, the reaction proposed earlier by Gogan and Chu [4f]. Thus, the final structure of the fragment may correspond to the phenylcyclopentadienylmanganese cation. This "reverse" migration of the $\mathrm{C}_{6} \mathrm{H}_{5}$ radical is indicated by the presence of a $\mathrm{C}_{5} \mathrm{H}_{4} \mathrm{C}_{6} \mathrm{H}_{5}^{+}$ion peak in the MI mass spectrum of $1 \mathrm{~d}$.

All of the ions in the MI mass spectrum of 1e can be explained as arising from the $2 \mathrm{e}$ isomer. The most abundant peak corresponds to $\mathrm{MnOH}^{+}$. Elimination of $\mathrm{CO}$ also proceeds from the $2 \mathrm{e}$ structure. The third type of fragment $\left(\mathrm{C}_{6} \mathrm{H}_{3} \mathrm{OMn}^{+}\right.$ions) may arise from $\mathrm{H}_{2} \mathrm{O}$ loss from both 1e and 2e ions, but note that in the case of the hydroxymethyl derivative, 1h (see below), a 1,3-elimination from the intact nido-cluster structure is not observed. Thus, if the 1,3-elimination does not take place in $1 \mathrm{~h}$ ions, it is even less likely to be effective for the relatively inflexible carboxyl derivative. Therefore, all the fragments in the $M \square$ mass spectrum of $\mathrm{MnC}_{5} \mathrm{H}_{4} \mathrm{COOH}^{+}$ions originate from the type 2 isomer, in good agreement with previous data on their reactivity toward crown ethers [3].

The MI mass spectrum of the formyl-substituted ion (1f) differs dramatically from the other acyl derivatives, with no peaks corresponding to a manganesecontaining ion. The only decomposition process observed is the formation of $\mathrm{C}_{6} \mathrm{H}_{5} \mathrm{O}^{+}$. The behavior of

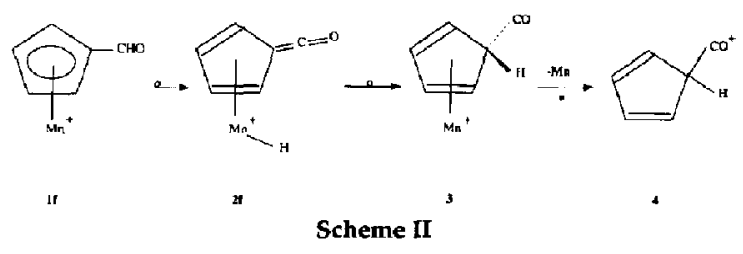

the formyl derivative cannot be predicted from thermochemical arguments. The effect of acyl substitution on the ionization energies of cyclopentadienyl radicals (e.g., using $\sigma^{+}$-substituent constants [9]) shows that the ionization energies for acylcyclopentadienyls should be significantly higher $(\geq 9 \mathrm{eV})$ than the ionization energy of the $\mathrm{Mn}$ atom $(7.435 \mathrm{eV})$.

Thus, isomerization of $1 \mathrm{f}$ ions before decomposition must be envisaged. The electron-impact mass spectrum of $(\mathrm{CO})_{3} \mathrm{MnC}_{5} \mathrm{H}_{4} \mathrm{CHO}$ shows an $\mathrm{MnH}^{+}$ion peak, which arises from hydrogen atom migration from the CHO group to the metal atom $[3,4 b, 4 f]$. The $2 f$ structure may be proposed to rearrange into structure 3 , the next isomer of 1 . If the hydrogen atom migrates directly to the cyclopentadienyl ring (Scheme TI), a "renovated" $\pi$-ligand is produced, although other sigmatropic isomers could in principle be involved. According to Scheme $\Pi$, ion 4 is the most probable structure for the organic ion resulting from $\mathrm{Mn}$ atom loss. The $\mathrm{C}_{6} \mathrm{H}_{5} \mathrm{O}^{+}$species could also have been the phenoxy ion, but its high ionization energy $(8.56 \mathrm{eV})$ rules it out.

The same rearrangement of 1 ions into type 3 structures can be proposed for the decomposition of metastable acetyl- and benzoyl-substituted derivatives via neutral metal atom loss.

\section{Methylene Derivatives, $\mathrm{MnC}_{5} \mathrm{H}_{4} \mathrm{CH}_{2} \mathrm{R}$}

In contrast with the data published by Efraty et al. [4e], the metastable peak for the $\mathrm{CH}_{3} \mathrm{C}_{5} \mathrm{H}_{4} \mathrm{Mn}^{+} \rightarrow \mathrm{Mn}^{+}$ transition was not observed in the present study. The main dissociation reaction of metastable $\mathrm{C}_{6} \mathrm{H}_{7} \mathrm{Mn}^{+}$ ions in the second field-free region of the $\mathrm{ZAB}-2 \mathrm{~F}$ mass spectrometer was manganese atom loss, forming the $\mathrm{C}_{6} \mathrm{H}_{7}^{+}$fraginent noted also in ref $4 \mathrm{a}$. The ions $\mathrm{MnH}^{+}$ and $\mathrm{C}_{6} \mathrm{H}_{6} \mathrm{Mn}^{+}$are also present in the MI mass spectrum but at low abundance. There are no obvious reasons for such a sharp change in the reactivity of nido-cluster $\mathrm{C}_{5} \mathrm{H}_{5} \mathrm{Mn}^{+}$and $\mathrm{CH}_{3} \mathrm{C}_{5} \mathrm{H}_{4} \mathrm{Mn}^{+}$ions because the ionization energy for the methylcyclopentadienyl radical ( $8.54 \mathrm{eV}$ [8]) is higher than that of $\mathrm{Mn}$ by more than $1 \mathrm{eV}$. Thus, for the $\mathrm{CH}_{3} \mathrm{C}_{5} \mathrm{H}_{4} \mathrm{Mn}^{+}$ion the dissociation into $\mathrm{Mn}^{+}+\mathrm{C}_{5} \mathrm{H}_{4} \mathrm{CH}_{3}$ is still thermodynamically preferable to decomposition to $\mathrm{Mn}+$ $\mathrm{C}_{5} \mathrm{H}_{4} \mathrm{CH}_{3}^{+}$. To explain this "unusual" behavior of $\mathrm{C}_{6} \mathrm{H}_{7} \mathrm{Mn}^{+}$ions, a facile isomerization of the nidocluster ions $1 \mathrm{~g}$, by analogy with that for $1 \mathrm{f}$, must be proposed.

The presence of $\mathrm{MnH}^{+}$ions in the MI mass spectrum can arise via hydrogen atom migration from the 


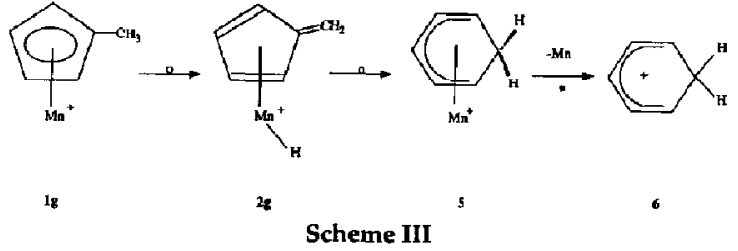

methyl group to the central metal atom as the first stage of the isomerization; but a type 2 structure cannot produce the $\mathrm{C}_{6} \mathrm{H}_{7}^{+}$ion without additional rearrangement. Therefore a reverse migration of hydride to the hydrocarbon ligand is proposed; therefore the final structure for decomposing ions $\mathrm{C}_{6} \mathrm{H}_{7} \mathrm{Mn}^{+}$differs significantly from $1 \mathrm{~g}$. Thus, a ring-expansion process leads to ion 5 (Scheme III). Note that there are some similarities in the behavior of $\mathrm{C}_{6} \mathrm{H}_{7} \mathrm{Mn}^{+}$ions derived from tricarbonylmanganese complexes containing fivemembered methylcyclopentadienyl and six-membered ( $\eta^{5}$-cyclohexadienyl) [12] ligands-in both cases, the metastable peaks due to $\mathrm{MnH}^{+}$and $\mathrm{C}_{6} \mathrm{H}_{7}^{+}$ions formation were found.

To further investigate the above proposal, the behavior of $\mathrm{C}_{6} \mathrm{H}_{7}^{+}$ions derived from ionized 1,3cyclohexadiene and from $\mathrm{CH}_{3} \mathrm{C}_{5} \mathrm{H}_{4} \mathrm{Mn}(\mathrm{CO})_{3}$ in the ion source were compared. The $\mathrm{C}_{6} \mathrm{H}_{7}^{+}$ions from $1,3-$ cyclohexadiene have the structure of protonated benzene, and the MI, CA, and NR mass spectra of this ion were identical to the corresponding spectra of ions from the organometallic precursor. Neither the MI nor the $\mathrm{CA}$ mass spectra contain the $\mathrm{C}_{5} \mathrm{H}_{5}^{+}$or $\mathrm{CH}_{2}^{+}$ions, which seems to be characteristic of the $\mathrm{C}_{5} \mathrm{H}_{5} \mathrm{CH}_{2}^{+}$ structure proposed in ref 2

Thus, methylcyclopentadienylmanganese ions are believed to rearrange into cyclohexadienylmanganese cations before decomposition in the second field-free region of the $\mathrm{ZAB}-2 \mathrm{~F}$ mass spectrometer. The most probable route from ion $1 \mathrm{~g}$ to ion 6 is via an intermediate of type 5 . The reverse migration of the endo hydrogen atom from the cyclohexadienyl ligand to the metal atom possibly does not take place.

The behavior of the hydroxymethyl-substituted ions 1h resembles that of the carboxyl derivative 1e. The main dissociation process leads to $\mathrm{MnOH}^{+}$ions, whose formation is associated with $\mathrm{OH}$-group migration from the substituent to the metal atom. The other significant fragments, which can originate from type 2 ions, are produced by elimination of $\mathrm{H}_{2}$ and $\mathrm{H}_{2} \mathrm{O}$ molecules, but the intact nido-cluster structure 1 h must also be considered a possible precursor for both fragment ions.

To identify the mechanisms for $\mathrm{C}_{6} \mathrm{H}_{5} \mathrm{OMn}^{+}$and $\mathrm{C}_{6} \mathrm{H}_{5} \mathrm{Mn}^{+}$ion formation, the MI mass spectra were recorded for labeled $1 \mathrm{~h}$ ions, containing one or two deuterium atoms in the cyclopentadienyl ring [in the $\alpha$-position(s) relative to the substituent]. The MI mass spectra of the deuterated ions do not show peaks due to $\mathrm{HD}$ or $\mathrm{D}_{2}$ loss. Therefore, only hydrogen atoms from the hydroxymethyl substituent of the intact
Table 2. Calculated and experimentally observed $\mathrm{HDO}: \mathrm{H}_{2} \mathrm{O}$ losses from $\mathrm{C}_{6} \mathrm{H}_{6} \mathrm{DOMn}^{+}$and $\mathrm{C}_{6} \mathrm{H}_{5} \mathrm{D}_{2} \mathrm{OMn}^{+}$ions in the metastable ion mass spectra of dideuterated $\mathbf{1 h}$

\begin{tabular}{ccc}
\hline Mechanism & $\mathrm{C}_{6} \mathrm{H}_{6} \mathrm{DOMn}^{+}$ & $\mathrm{C}_{6} \mathrm{H}_{5} \mathrm{D}_{2} \mathrm{OMn}^{+}$ \\
\hline A & $50: 50$ & $100: 0$ \\
B & $25: 75$ & $50: 50$ \\
C & $0: 100$ & $0: 100$ \\
D & $83: 17$ & $67: 33$ \\
Observed ( \pm 1$)$ & $86: 14$ & $73: 27$ \\
\hline
\end{tabular}

nido-cluster ions $1 \mathrm{~h}$ are involved in the elimination of $\mathrm{H}_{2}$, leading to the formylcyclopentadienylmanganese ions (1f).

Ion $\mathbf{1 h}$ is a likely precursor for $\mathrm{C}_{6} \mathrm{H}_{5} \mathrm{Mn}^{+}$ions too, involving a 1,3-elimination of $\mathrm{H}_{2} \mathrm{O}$ and including the hydrogen atom from the $\alpha$-position of the cyclopentadienyl ring (Table 2, mechanism $A$ ). This would lead to only $\mathrm{HDO}$ loss being possible from [2,5$\left.\mathrm{D}_{2} \mathrm{C}_{5} \mathrm{H}_{2} \mathrm{CH}_{2} \mathrm{OH}\right] \mathrm{Mn}^{+}$ions; however, the $\mathrm{MI}$ mass spectrum of these ions showed peaks corresponding to both $\mathrm{HDO}$ and $\mathrm{H}_{2} \mathrm{O}$ elimination (Table 2). Therefore other mechanisms for water elimination have to be proposed (Table 2): mechanism B: elimination from Structure $\mathbf{2 h}$, with participation of cyclopentadienyl ring hydrogen; mechanism C: elimination from Structure $2 \mathrm{~h}$, with participation of methylene hydrogen only; mechanism D: water loss from any structure with equivalent hydrogen atoms. In Table 2 are listed the observed $\mathrm{HDO} / \mathrm{H}_{2} \mathrm{O}$ loss ratios and those calculated for mechanisms $A-D$. Table 2 shows that only mechanism $\mathrm{D}$ is in agreement with the experimental data. The small excess of $\mathrm{H}_{2} \mathrm{O}$ loss may result from a primary isotope effect $\left(k_{H} / k_{D} \approx 1.09\right)$ or by some interference due to incomplete labeling. The randomization of six hydrogen atoms prior to water elimination can be rationalized by Scheme IV. Ion $1 \mathrm{~h}$ rearranges into the $2 h$ structure by migration of the hydroxyl group to the central metal atom. Expansion of the five-membered ring then leads to ion 7 , which contains the benzene ligand having six equivalent hydrogen atoms.

Some indication of the manganese-containing ion rearrangement reactions were deduced from the decomposition processes leading to the metal-free organic ions. The structures of organic ions derived from the manganese-containing precursors, namely, $\mathrm{C}_{6} \mathrm{H}_{5} \mathrm{O}^{+}$and $\mathrm{C}_{6} \mathrm{H}_{7}^{+}$, have been considered earlier [2]. For example, according to the previous quantum chemical calculations, Structures 4 and 6 are not the most stable ions of composition $\mathrm{C}_{6} \mathrm{H}_{5} \mathrm{O}^{+}$and $\mathrm{C}_{6} \mathrm{H}_{7}^{+}$, respectively [2, 13]; however we have not observed

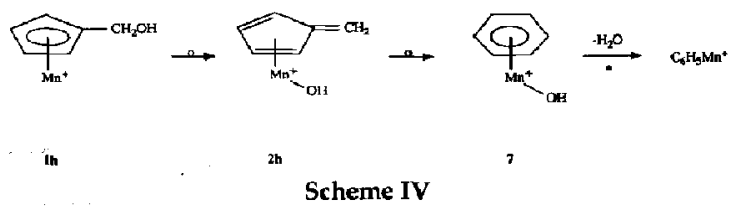


any indication of the formation of these stable nidocluster structures (Structures $\mathbf{8}$ and 9). This can be explained in two ways. First, the transformation of ligand(s) in the coordination sphere of the transition metal atom are strongly controlled by the central metal atom. Only a definite number of isomerization processes, usually stereochemically selected [11b], are permitted, and they do not necessarily lead to the most stable isomers. Second, if the organic ion formed on the decomposition of the metal-containing precursor is not the most stable isomer for the given composition, its transition into the more stable isomer(s) requires the loss of excess energy, and therefore, in general, their decomposition processes should be accompanied by large kinetic energy releases. This proposal is not in keeping with the observed kinetic energy loss on the fragmentation of $\mathrm{C}_{6} \mathrm{H}_{5} \mathrm{O}^{+}$ions on $\mathrm{C}_{5} \mathrm{H}_{5}^{+}+\mathrm{CO}$, for which $T_{05}$ is only $20 \mathrm{meV}$.

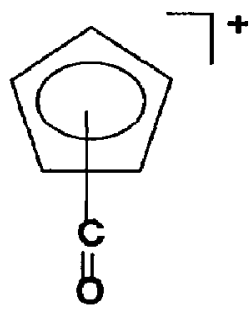

8

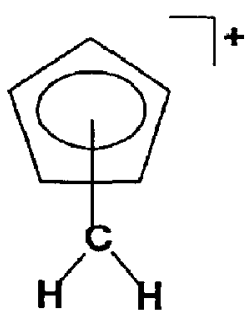

9

\section{Conclusions}

The MI mass spectra of $\mathrm{RXC}_{3} \mathrm{H}_{4} \mathrm{Mn}^{+}$ions show that only unsubstituted and cyano derivatives entirely retain their initial nido-cluster type 1 structure. For the other substituents, considerable isomerization occurs, the degree of which depends on the nature of the RX group. For the carbonyl, $\mathrm{X}=\mathrm{CO}$, and methylene, $\mathrm{X}=$ $\mathrm{CH}_{2}$, derivatives, from partial to complete isomeriza- tion of 1 ions into the type 2 structure takes place by the well-known migration of a radical (usually from the $\beta$-position of the side chain) to the positively charged central metal atom. Ions of type 2 are the key intermediates for further rearrangements [e.g., ring expansion (for the ions initially containing a methylene group connected with the cyclopentadienyl ring] and "reverse" migration of the radical $\mathrm{R}$ from the metal atom into the $\pi$-ligand. The degree of type 1 ion isomerization (in decomposing ions) may be estimated from the inverse ratio of the summed peak intensities corresponding to type 1 ions to the summed intensity of all the other peaks in the MI mass spectra. These values ( $Z$ ) are listed in Table 1 . The series of $Z$ values obtained in this work differs from that derived from the reactivity of gas-phase $\mathrm{RXC}_{5} \mathrm{H}_{4} \mathrm{Mn}^{+}$ions toward crown ethers [3] or on their relative abundances in the ion source of the mass spectrometer $[2,14]$. The main discrepancies are in the position of the $\mathrm{CHO}$ substituent among the carbonyl derivatives, which despite the previous data $[2,3]$ behave like the carboxyl derivative and unlike the acetyl- and benzoylsubstituted ions, and of methylene-containing ions ( $X$ $=\mathrm{CH}_{2}$ ) relative to their carbonyl analogues having the same $\mathrm{R}$ groups. These differences result from the specific conditions of the MI experiment, which observes the decomposition of ions with a narrow internal energy spread and in a limited time (microsecond) frame: The isomeric composition of stable ions differs from that indicated by the MI mass spectra because the energy required for the simple metal $-\eta^{5}$-cyclopentadienyl ligand bond cleavage for (most of) the $\mathrm{RXC}_{5} \mathrm{H}_{4} \mathrm{Mn}^{+}$ions exceeds the energy necessary for isomerization into type 2 structures and their further decomposition or fragmentation.

Data from the MI decompositions do not exclude the possible existence of stable type 1 structures. This is confirmed by analysis of the CA mass spectra of $\mathrm{RXC}_{5} \mathrm{H}_{4} \mathrm{Mn}^{+}$ions (Table 3). Most of them contain "bare" metal ion peaks arising from the dissociation of type 1 structures. Hence the energy transmitted to

Table 3. Collisional activation mass spectra of ions 1a-1h $\left(\mathrm{L}=\mathrm{RXC}_{5} \mathrm{H}_{4}\right)$

\begin{tabular}{|c|c|}
\hline Ion & Fragment ions (relative intensity, \%) \\
\hline $\begin{array}{l}1 \mathrm{a} \\
1 \mathrm{~b} \\
1 \mathrm{c}\end{array}$ & 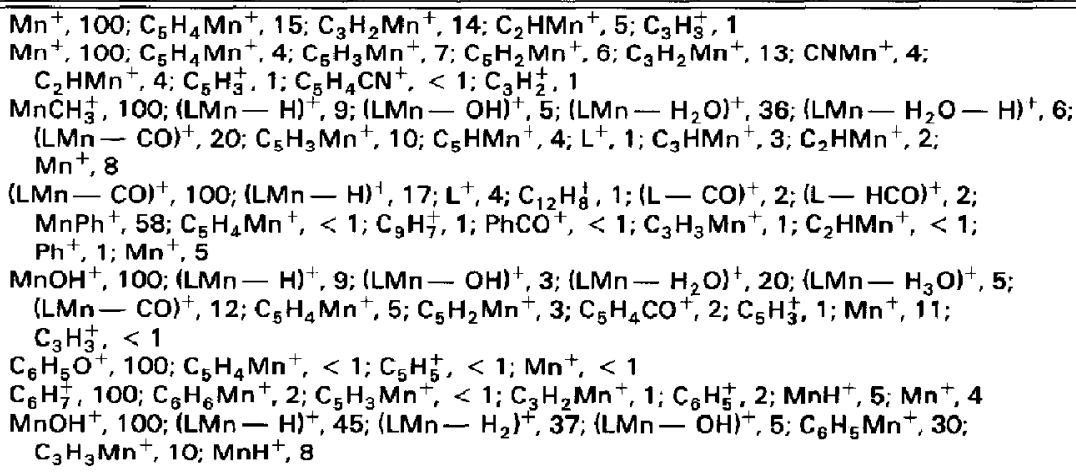 \\
\hline
\end{tabular}




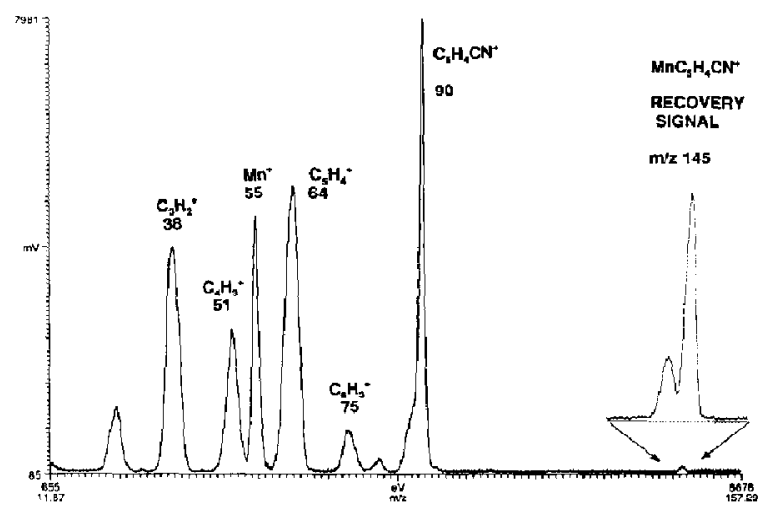

Figure 1. NR mass spectrum $\left(\check{X e}, 90 \% \mathrm{~T} / \mathrm{O}_{2}, 85 \% \mathrm{~T}\right)$ of the $\mathrm{MnC}_{5} \mathrm{H}_{4} \mathrm{CN}^{+}$ion (1b).

stable ions of type 1 on a single collision with target gas is enough to initiate their dissociation.

The exception is the behavior of ions with $\mathrm{R}=\mathrm{OH}$ (1f and 1h). Their CA mass spectra do not display a $\mathrm{Mn}^{+}$ion peak. It is concluded that, in these cases, the energy required for the type 1 ion to rearrange into the type 2 structure is very small. Thus, even though the stable ions exist as type 1 species, their isomerization into type 2 structures following collision is fast. The NR mass spectra of these two ions also differ from the NR mass spectra of the other derivatives, showing no recovery signal for $1 \mathrm{~g}$ and a very weak recovery signal for 1 h.

Except for the presence or absence of the recovery signal, the NR mass spectra provide less information about the $\mathrm{RXC}_{5} \mathrm{H}_{4} \mathrm{Mn}^{+}$ion structures. All of the NR mass spectra (see, for example, Figures $1-5$ for $1 \mathrm{~b}$ and 1d-1g ions) show abundant $\mathrm{Mn}^{+}$ions. The NR mass spectra contain significant $\mathrm{Mn}^{+}$yields (unlike the $\mathrm{CA}$ mass spectra) whose origin is uncertain; for example, they could be formed from neutral $\mathrm{Mn}$ atoms generated from neutral intermediates and from reionized MnR species (see, e.g., the NR mass spectra of $\mathrm{MnOH}^{+}$ and $\mathrm{MnC}_{6} \mathrm{H}_{5}^{+}$ions, Figures 6 and 7).

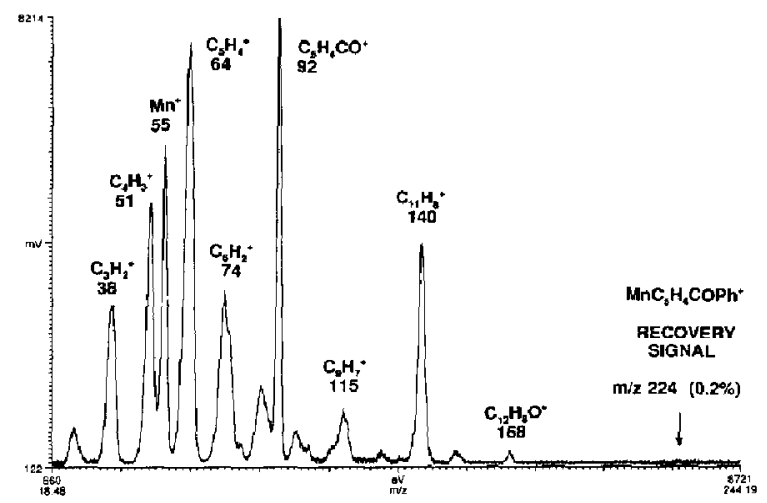

Figure 2. NR mass spectrum $\left(\mathrm{Xe}_{,}, 90 \% \mathrm{~T} / \mathrm{O}_{2}, 85 \% \mathrm{~T}\right)$ of the $\mathrm{MnC}_{5} \mathrm{H}_{4} \mathrm{COPh}^{+}$ion (1d).

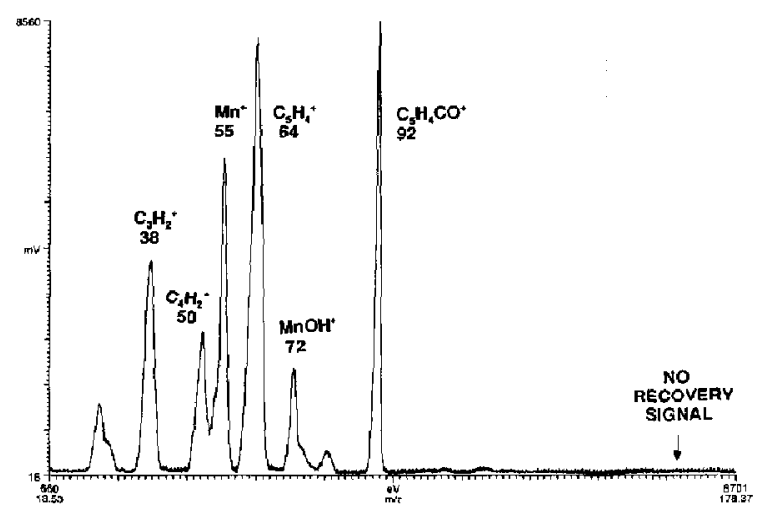

Figure 3. NR mass spectrum $\left(X e, 90 \% \mathrm{~T} / \mathrm{O}_{2}, 85 \% \mathrm{~T}\right)$ of the $\mathrm{MnC}_{5} \mathrm{H}_{4} \mathrm{COOH}^{+}$ion (1e).

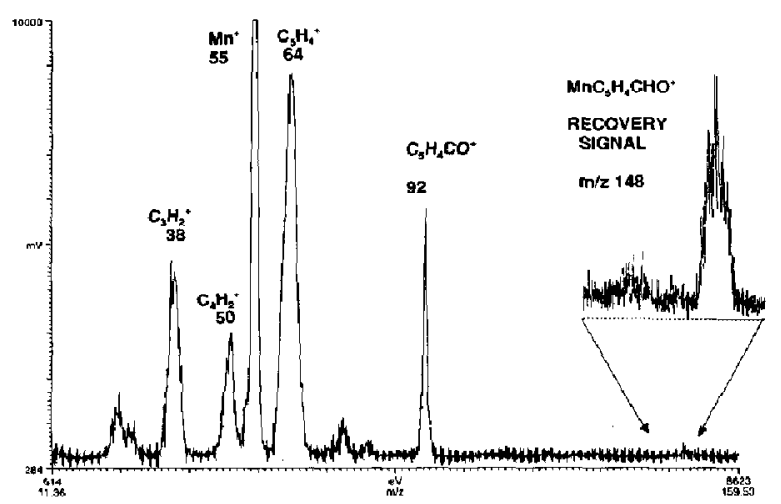

Figure 4. $\mathrm{NR}$ mass spectrum $\left(\mathrm{Xe}, 90 \% \mathrm{~T} / \mathrm{O}_{2}, 85 \% \mathrm{~T}\right)$ of the $\mathrm{MnC}_{5} \mathrm{H}_{4} \mathrm{CHO}^{+}$ion (1f).

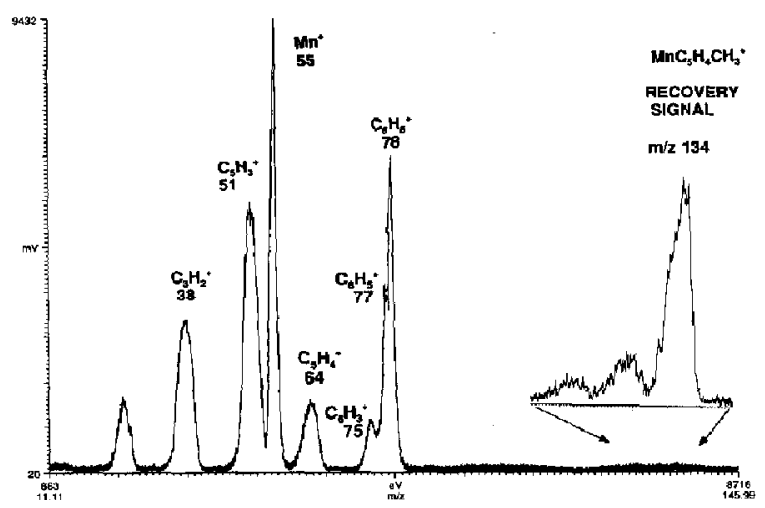

Figure 5. NR mass spectrum $\left(\mathrm{Xe}, 90 \% \mathrm{~T} / \mathrm{O}_{2}, 85 \% \mathrm{~T}\right)$ of the $\mathrm{MnC}_{5} \mathrm{H}_{4} \mathrm{CH}_{3}^{+}$ion (1g).

Only $1 \mathrm{a}$ and $\mathbf{1 b}$ ions show metal-free cyclopentadienyl ligand ions $\left(\mathrm{C}_{5} \mathrm{H}_{5}^{+}\right.$and $\mathrm{C}_{5} \mathrm{H}_{4} \mathrm{CN}^{+}$, respectively). The NR mass spectra of $1 \mathrm{c}-1 \mathrm{~h}$ contain $\mathrm{C}_{5} \mathrm{H}_{4} \mathrm{X}^{+}$ions, which can originate from the reionized type 2 structure, from decomposition of reionized $\mathrm{C}_{5} \mathrm{H}_{4} \times \mathrm{R}$ species, and from the reionization of $\mathrm{C}_{5} \mathrm{H}_{4} \mathrm{X}$ neutral molecules. 


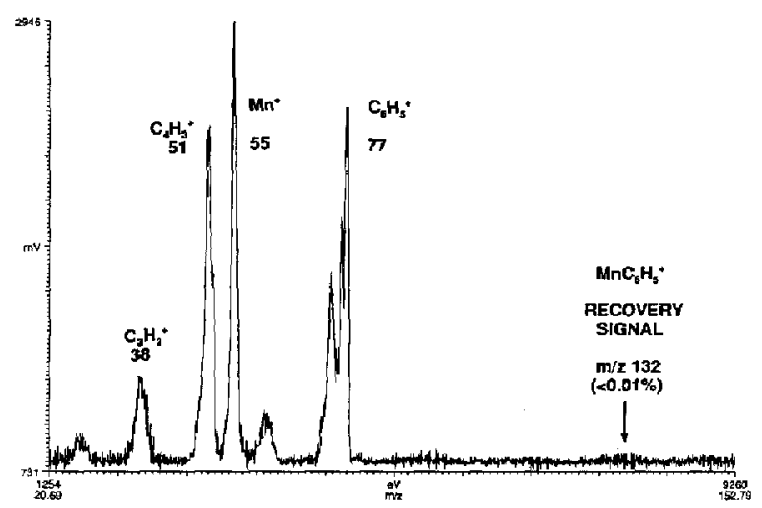

Figure 6. NR mass spectrum $\left(\mathrm{Xe}, 90 \% \mathrm{~T} / \mathrm{O}_{2}, 85 \% \mathrm{~T}\right)$ of the $\mathrm{MnC}_{6} \mathrm{H}_{5}^{+}$ion.

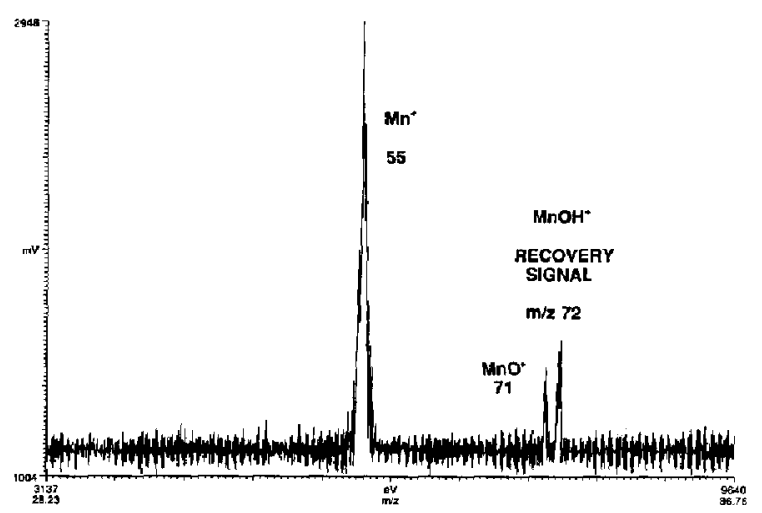

Figure 7. NR mass spectrum $\left(\mathrm{Xe}, 90 \% \mathrm{~T} / \mathrm{O}_{2}, 85 \% \mathrm{~T}\right)$ of the $\mathrm{MnOH}^{+}$ion.

\section{Acknowledgments}

JLH thanks the Natural Science and Engineering Research Council of Canada for continuing financial support, and DVZ acknowledges their International Scientific Exchange award during the tenure of which this work was completed.

\section{References}

1. (a) Werner, H. I. Organomet. Chem. 1980, 200, 335-348; (b) McNair, A. M.; Mann, K. R. Inorg. Chem. 1986, 25, 2519-2527; (c) Gill, T. P.; Mann, K. R. Organometallics 1982, 1, 485-488; (d) McNair, A. M.; Boyd, D. C.; Manr, K. R. Organometallics 1986, 5, 303-310; (e) Kudinov, A. R.; Rybinskaya, M. I. Dokl. Akad. Nauk SSSR 1987, 293, 1137-1139; (f) Kudinov, A, R; Rybinskaya, M. I.; Struchkov, Yu. T.; Yanovskii, A. I.; Petrovskii, P. V. I. Organomet. Chem. 1987, 336, 187-197; (g) Kudinov, A. R.; Muratov, D. N.; Rybinskaya, M. I.; Petrovskii, P. V.; Mironov, A. V.; Timofeeva, T. V.; Slovokhotov, Yu. L.; Struchkov, Yu. T. I. Organomet. Chem. 1991, 414, 97-107; (h) Kudinov, A. R.; Rybinskaya, M. I. Metalloorg. Khim. (SSSR) 1988, 1, 1431-1438; (i) Novikova, L. N.; Ustynyk, N. A.; Denisovich, L. I.; Peterleitner, M. G.; Kukharenko, S. V.; Streletz, V. V.; Oprunenko, Yu. F. Metalloorg. Khim. (SSSR) 1991, 4, 871-877.

2. Sizoi, V. F, Nekrasov, Yu. S. Izo. Akad. Nauk SSSR, Ser. Khim. 1982, 285-292.

3. Zagorevskii, D. V.; Nekrasov, Yu. S. J. Urganomet. Chem. 1984, 267, 121-126.

4. (a) Winters, R. E; Kiser, R. W. I. Organomet. Chem. 1965, 4, 190-197; (b) Tirosh, N.; Modiano, A.; Cais, M. J. Organomet. Chem. 1966, 5, 357-361; (c) Müller, J.; Herberhold, M. J. Organomet. Chem. 1968, 13, 399-410; (d) Cais, M.; Lupin, M. S.; Maoz, M.; Sharvit, J. J. Chem. Soc. A 1968, 3086-3095; (e) Efraty, A.; Huang, M. H. A.; Weston, C. A. Inorg. Chem. 1975, 14, 2796-2799; (f) Gogan, J.; Chu, C.-K. Org. Mass Spectrom. 1977, 12, 343-347; (g) Christopher, R. E.; Venanzi, L. M. Inorg. Chim. Acta 1973, 7, 219-225.

5. (a) Nesmeyanov, A. N.; Anisimov, K. N.; Valueva, Z. P. Dokl. Akad. Navk SSSR 1965, 162, 112; (b) Nesmeyanov, A. N.; Kolobova, N. F.; Anisimov, K. N.; Makarnv, Yu. V. Izo. Akad. Nauk SSSR, Ser. Khim. 1967, 953.

6. (a) Burgers, P. C; Holmes, J. L.; Szulejko, J. E; Mommers, A. A.; Terlouw, J. K. Org. Mass Spectrom. 1983, I8, 254-262; (b) Morgan, R. P.; Beynon, J. H.; Bateman, R. H.; Green, B. N. Int. J. Mass Spectrom. Ion Phys. 1978, 28, 171-191.

7. Lias, S. G.; Bartmess, J. E.; Liebman, J. F.; Holmes, J. L; Levin, R. D.; Mallard, W. G. I. Phys. Chem. Ref. Data 1978, 17. Suppl. 1.

8. Stevenson, D. P. Discuss. Faraday Soc. 1951, 10, 35-45.

9. Pottie, R. F.; Lossing, F. P. I. Am. Chem. Soc. 1963, 85, 269-271.

10. Zagorevskii, D. V.; Volkova, T. V.; Yakushin, S. O.; Antipov, B. G.; Nekrasov, Yu. S. Org. Mass Spectrom. 1991, 26, 748-750.

11. (a) Müller, J. Angew. Chem. Int. Ed. Engl. 1972, 11, 653-665; (b) Nekrasov, Yu. S.; Zagorevskii, D. V. Org. Mass Spectrom. 1991, 26, 733-738.

12. King, R. B.; Ackermann, M. N. Org. Mass Spectrom. 1974, 9, 190-194.

13. Nekrasov, Yu. S. Thesis, Institute of Organo-Element Compounds, Moscow, 1983.

14. Zagorevskii, D. V.; Nekrasov, Yu. S. Metalloorg. Khim. (SSSR) 1992,5 , in press. 